\title{
Complexometric Determination of Thallium(III) using Ethanethiol as a Selective Masking Agent
}

\author{
J. Karthikeyan, ${ }^{a}$ P. Parameshwara, ${ }^{a}$ A. Nityananda Shetty ${ }^{*, a}$ and Prakash Shetty ${ }^{b}$ \\ ${ }^{a}$ Department of Chemistry, National Institute of Technology Karnataka, Surathkal Srinivasnagar- \\ 575025 Karnataka, India \\ ${ }^{b}$ Department of Chemistry, Manipal Institute of Technology, Manipal-576 119 Karnataka, India
}

\begin{abstract}
Um método complexométrico simples e seletivo é proposto para a determinação de tálio na presença de outros metais, pela habilidade do etanetiol em mascarar seletivamente íons tálio (III). Em solução, o tálio presente foi inicialmente complexado com um excesso conhecido de EDTA, sendo o excesso titulado com uma solução padrão de sulfato de zinco em pH 5-6 (hexamina), usando-se xilenol como indicador. Uma solução aquosa de etanetiol $0,3 \%$ foi então adicionada para deslocar o EDTA do complexo Tl(III)-EDTA. O EDTA livre foi titulado com solução padrão de sulfato de zinco, como anteriormente. Resultados reprodutíveis e precisos foram obtidos na faixa de $3,70 \mathrm{mg}$ a $74,07 \mathrm{mg}$ de $\mathrm{Tl}(\mathrm{III})$, com erro relativo menor do que $\pm 0,44 \%$ e um coeficiente de variação menor do que $0,27 \%$. A interferência de vários íons foi estudada e o método foi usado para análise de tálio em misturas de ligas sintéticas e também em complexos.
\end{abstract}

A simple and selective complexometric method for the determination of thallium in presence of other metal ions is proposed based on the selective masking ability of ethanethiol towards thallium(III). Thallium present in a given sample solution is first complexed with a known excess of EDTA and the surplus EDTA is titrated with standard zinc sulphate solution at $\mathrm{pH}$ 5-6(hexamine) using xylenol orange as the indicator. A $0.3 \%$ aqueous solution of ethanethiol is then added to displace EDTA from the Tl(III)-EDTA complex. The released EDTA is titrated with standard zinc sulphate solution as before. Reproducible and accurate results are obtained for $3.70 \mathrm{mg}$ to $74.07 \mathrm{mg}$ of $\mathrm{Tl}$ (III) with relative error less than $\pm 0.44 \%$ and coefficient of variation not more than $0.27 \%$. The interference of various ions was studied and the method was used for the analysis of thallium in its synthetic alloy mixtures and also in complexes.

Keywords: thallium determination, masking agent, ethanethiol

\section{Introduction}

Thallium alloys and its complexes find various applications in diverse fields such as photo-electric cells, insoluble anodes, corrosion inhibitors and fungicides. Considering these excellent and extensive applications of thallium alloys and its complexes, a reliable and rapid method is often essential for the determination of thallium in a single stage.

Owing to poor selectivity, earlier complexometric methods,${ }^{1,2}$ for thallium could not be used for the

* e-mail: nityashreya@rediffmail.com determination in its alloys. Complexometric titrations particularly those involving masking and demasking technique are of considerable importance as they provide simple and rapid method for the determination of a specific desired metal ion in the presence of associated metal ions. In the determination of thallium by this technique, it is first complexed with EDTA followed by selective decomposition of Tl-EDTA complex with the suitable masking agent. The released EDTA is back titrated with suitable titrant. Literature survey shows that a number of sulphur-nitrogen donor ligands such as thiopyrene, ${ }^{3}$ thiosemicarbazide, ${ }^{4}$ hydrazine sulphate, ${ }^{5} 2$ mercapto ethanol, ${ }^{6}$ thiocarbohydrazide, ${ }^{7}$ ascorbic acid, ${ }^{8}$ 
DL-cysteine, ${ }^{9}$ 3-mercapto-1,2-propanediol, ${ }^{10}$ ethylene thiourea, ${ }^{11}$ sodium sulfite, ${ }^{12}$-thiazoline-2-thiol, ${ }^{13}$ hydroxylamine hydrochloride, ${ }^{14}$ semicarbazide hydrochloride, ${ }^{15}$ thiosulfate, ${ }^{16}$ thiourea, ${ }^{17}$ cysteamine hydrochloride, ${ }^{18}$ thioglycolic acid, ${ }^{19}$ oxalic acid, ${ }^{20}$ etc. have been used as selective masking agents in the complexometric determination of Tl(III). Some of these methods either require heating or re-adjustment of $\mathrm{pH}$ for the quantitative release of EDTA from Tl-EDTA complex. In many of the methods, $\mathrm{Cu}$ (II) interferes and many other ions show interference in other methods. A comparison of the reported methods with the presently proposed method is given in the Table 1 .

The present investigation describes, ethanethiol as a selective masking agent in the complexometric determination of thallium(III). The effects of foreign ions have been studied and application of the method in the determination of thallium in its complexes and synthetic alloy mixtures has been reported.

\section{Experimental}

\section{Reagents and chemicals}

All reagents used were of analytical or chemically pure grade. A Thallium nitrate solution was prepared as per the reported procedure. ${ }^{21} \mathrm{~A}$ known weight of thallous nitrate was dissolved in minimum amount of water, oxidized to $\mathrm{Tl}(\mathrm{III})$ by alkaline bromine, separated and purified by precipitation as $\mathrm{Tl}(\mathrm{OH})_{3}$. It was then dissolved in dilute $\mathrm{HCl}$, made up to the mark with distilled water and standardized by the chromate method and thionalide method. ${ }^{22}$ Zinc sulphate solution $\left(0.02 \mathrm{~mol} \mathrm{~L}^{-1}\right)$ was prepared from an analytical reagent grade sample, and was standardized gravimetrically by the oxinate method and quinaldinate method. ${ }^{22}$ EDTA solution $(\sim 0.04 \mathrm{~mol}$ $\mathrm{L}^{-1}$ ) was prepared by dissolving the di-sodium salt of EDTA in distilled water. Freshly prepared $0.5 \%$ aqueous solution of the xylenol orange indicator was used. Ethanethiol was used as a $0.3 \%$ solution in distilled water. Solutions of various metal ions were prepared by dissolving the appropriate metal salts in distilled water or with suitable acids.

\section{Procedure}

To an aliquot of the solution containing 3.70 -74.07 mg of thallium solution and varying amounts of diverse metal ions taken in a $250 \mathrm{~mL}$ conical flask, an excess of $0.04 \mathrm{~mol} \mathrm{~L}^{-1}$ EDTA solution was added. The solution was diluted with $20 \mathrm{~mL}$ of distilled water. The $\mathrm{pH}$ of the solution was adjusted to between 5-6 by adding solid hexamine. Excess EDTA was back titrated with standard zinc sulphate solution to the sharp color change of xylenol orange indicator from yellow to red. A $0.3 \%$ aqueous solution of ethanethiol was added (just above 1:10 molar ratio $M: L)$, shaken well and allowed to stand for two minutes. The released EDTA was back titrated with standard zinc sulphate solution to the same end point as before. The second titre value is equivalent to the thallium content present in the aliquot.

\section{Analysis of thallium complexes}

A number of thallium(I) complexes with 5-amino-2mercapto-1,3,4-thiadiazole, 4-amino-5-mercapto-3methyl-1,2,4-triazole, 4-amino-3-ethyl-5-mercapto-1,2,4triazole, 4-amino-5-mercapto-3-n-propyl-1,2,4-triazole

Table 1. Comparison of the reported reagents with the proposed reagent

\begin{tabular}{|c|c|c|}
\hline Reagent & Interfering ions & Reference \\
\hline Thiosemicarbazide & $\mathrm{Hg}(\mathrm{II}), \mathrm{Cu}(\mathrm{II}), \mathrm{Fe}(\mathrm{II}), \mathrm{Pd}(\mathrm{II}), \mathrm{Sn}(\mathrm{II}), \mathrm{Cr}(\mathrm{III}), \mathrm{Bi}(\mathrm{III})$ and $\mathrm{Al}(\mathrm{III})$ & 4 \\
\hline Hydrazine sulphate & $\mathrm{Cr}(\mathrm{III}), \mathrm{Mn}(\mathrm{II}), \mathrm{Sn}(\mathrm{IV}), \mathrm{Pd}(\mathrm{II}), \mathrm{Ga}(\mathrm{III}), \mathrm{In}(\mathrm{III})$ and $\mathrm{Al}(\mathrm{III})$ & 5 \\
\hline 2-mercaptoethanol & $\mathrm{Pd}(\mathrm{II}), \mathrm{Hg}(\mathrm{II}), \mathrm{Cu}(\mathrm{II}), \mathrm{Cr}(\mathrm{III})$ and $\mathrm{Sn}(\mathrm{IV})$ & 6 \\
\hline Thiocarbohydrazide & $\mathrm{Cu}(\mathrm{II}), \mathrm{Pd}(\mathrm{II}), \mathrm{Hg}(\mathrm{II}), \mathrm{Bi}(\mathrm{III}), \mathrm{Zr}$ (III) and $\mathrm{Sn}(\mathrm{IV})$ & 7 \\
\hline Ascorbic acid & $\mathrm{Ag}(\mathrm{I}), \mathrm{Cu}(\mathrm{II}), \mathrm{Hg}(\mathrm{II}), \mathrm{Pb}(\mathrm{II}), \mathrm{Au}(\mathrm{III}), \mathrm{Sb}(\mathrm{IV})$ and $\mathrm{Sn}(\mathrm{IV})$ & 8 \\
\hline DL-Cysteine & $\mathrm{Cu}(\mathrm{II}), \mathrm{Pd}(\mathrm{II})$ and $\mathrm{Hg}(\mathrm{II})$ & 9 \\
\hline 3-Mercapto-1,2-propanediol & $\mathrm{Pd}(\mathrm{II}), \mathrm{Hg}(\mathrm{II}), \mathrm{Cu}(\mathrm{II}), \mathrm{Cr}(\mathrm{III})$ and $\mathrm{Sn}(\mathrm{IV})$ & 10 \\
\hline Ethylene thiourea & $\operatorname{Ag}(\mathrm{I}), \mathrm{Hg}(\mathrm{II})$ and $\mathrm{Sn}(\mathrm{IV})$ & 11 \\
\hline Sodium sulfite & $\mathrm{Hg}(\mathrm{II}), \mathrm{Pd}(\mathrm{II})$ and $\mathrm{Sn}(\mathrm{IV})$ & 12 \\
\hline 2-Thiazoline-2-thiol & $\mathrm{Hg}(\mathrm{II}), \mathrm{Pd}(\mathrm{II}), \mathrm{Cu}(\mathrm{II}), \mathrm{Fe}(\mathrm{III}), \mathrm{Al}(\mathrm{III}) \mathrm{V}(\mathrm{III}), \mathrm{Cr}(\mathrm{III}), \mathrm{Ce}(\mathrm{IV})$ and $\mathrm{Sn}(\mathrm{IV})$, & 13 \\
\hline Hydroxylamine hydrochloride & $\operatorname{Ag}(\mathrm{I}), \mathrm{Hg}(\mathrm{II}), \mathrm{Pd}(\mathrm{II}), \mathrm{Au}(\mathrm{III}), \mathrm{Sb}(\mathrm{IV})$ and $\mathrm{Sn}(\mathrm{IV})$ & 14 \\
\hline Thiosulfate & $\mathrm{Pd}(\mathrm{II}), \mathrm{Hg}(\mathrm{II}), \mathrm{Au}(\mathrm{III}), \mathrm{Zr}(\mathrm{III})$ and $\mathrm{Sn}(\mathrm{IV})$ & 16 \\
\hline Thiourea & $\mathrm{Cu}(\mathrm{II}), \mathrm{Pd}(\mathrm{II}), \mathrm{Hg}(\mathrm{II}), \mathrm{Zr}(\mathrm{III})$ and $\mathrm{Sn}(\mathrm{IV})$ & 17 \\
\hline Cysteamine hydrochloride & $\mathrm{Cu}(\mathrm{II}), \mathrm{Pd}(\mathrm{II})$ and $\mathrm{Sn}(\mathrm{IV})$ & 18 \\
\hline Thioglycolic acid & $\mathrm{Pd}(\mathrm{II}), \mathrm{Hg}(\mathrm{II}), \mathrm{Cu}(\mathrm{II}), \mathrm{Cr}(\mathrm{III})$ and $\mathrm{Sn}(\mathrm{IV})$ & 19 \\
\hline Ethanethiol & $\mathrm{Hg}(\mathrm{II}), \mathrm{Pd}(\mathrm{II})$ and $\mathrm{Sn}(\mathrm{IV})$. For $\mathrm{Hg}(\mathrm{II})$ interference obviated by using acetyl acetone. & Proposed reagent \\
\hline
\end{tabular}


were prepared and purified as per the reported methods. ${ }^{28,29}$ A known weight of the complex was decomposed by evaporation to near dryness with aqua-regia. The residue was then cooled, dissolved in $3 \mathrm{~mL}$ of dilute $\mathrm{HNO}_{3}$, and made up to $250 \mathrm{~mL}$ with distilled water. Aliquots of the made up solution were used for titration as per the proposed method using ethanethiol as a masking agent.

\section{Result and Discussions}

\section{Mechanism of demasking}

Generally, a metal, which can exist in two different oxidation states, differs in its tendency to form a stable complex with EDTA at different oxidation states. Thallium is one such element, which forms a stable complex with EDTA $(\log \mathrm{K}=22.5)$ in its trivalent state, ${ }^{23}$ but shows little tendency for complexation with EDTA in its monovalent state. ${ }^{24}$ Even if thallium (I) forms complex with EDTA it may do so only in the basic medium (pH 8-9) and complete decomposition of $\mathrm{Tl}(\mathrm{I})$ EDTA complex takes place in the acidic medium. ${ }^{25}$ Therefore, the redox behavior of $\mathrm{Tl}(\mathrm{III})-\mathrm{Tl}(\mathrm{I})$ can be conveniently employed in acidic medium for its complexometric determination by demasking technique.

Being a good reducing agent, ethanethiol effectively reduces $\mathrm{Tl}(\mathrm{III})$ to $\mathrm{Tl}(\mathrm{I})$ by a 2 -electron change process. ${ }^{26}$ The redox reaction can be represented as follows

$$
\begin{aligned}
& 2 \mathrm{R}-\mathrm{S}-\mathrm{H} \longrightarrow \mathrm{R}-\mathrm{S}-\mathrm{S}-\mathrm{R}+2 \mathrm{H}^{+}+2 \mathrm{e}^{-}\left(\mathrm{R}=-\mathrm{C}_{2} \mathrm{H}_{5}\right) \\
& \mathrm{Tl}^{3+}+2 \mathrm{e}^{-} \longrightarrow \mathrm{Tl}^{+}
\end{aligned}
$$

Ethanethiol thus selectively demasks thallium from Tl(III)-EDTA complex through a change in the oxidation state of thallium (reduction) and thereby releases EDTA quantitatively. Besides changing the oxidation state of thallium, ethanethiol forms a stable and soluble complex with $\mathrm{Tl}(\mathrm{I})$ so formed. The +1 oxidation state of thallium in its complex was confirmed by spot test, ${ }^{27}$ a red precipitate was formed when a solution of the complex in dilute hydrochloric acid was treated with a drop each of bismuth nitrate solution and sodium iodide solution.

\section{Effect of reagent concentration}

Preliminary experimental results showed that addition of ethanethiol in 1:10 molar ratio (M:L) was required for the quantitative release of EDTA from Tl(III)-EDTA complex at room temperature. However, no adverse effects on the results were observed even on adding 10 fold excess over the required quantity of the reagent. In all our subsequent determinations the concentration of the reagent was maintained at slightly above the required molar ratio.

\section{Accuracy and precision}

In order to study the accuracy and precision of the method, determinations of thallium in the concentration range of $3.70-74.07 \mathrm{mg}$ were carried out under optimized experimental conditions. These results are presented in Table 2. The results show that the maximum relative error does not exceed $\pm 0.44 \%$ and coefficient of variation not more than $\pm 0.27 \%$. From these results, it is reasonable to infer that the proposed method is precise and accurate.

Table 2. Precision and accuracy in the determination of Tl(III)

\begin{tabular}{ccccc}
\hline $\begin{array}{c}\text { Thallium } \\
\text { Taken }\end{array}$ & $\begin{array}{c}\text { Found } \\
\text { Found }^{\mathrm{a}}\end{array}$ & $\begin{array}{c}\text { Relative } \\
\text { error }(\%)\end{array}$ & $\begin{array}{c}\text { Standard } \\
\text { deviation }\end{array}$ & $\begin{array}{c}\text { Coefficient of } \\
\text { variation }(\%)\end{array}$ \\
\hline 3.70 & 3.69 & -0.27 & 0.01 & 0.27 \\
7.40 & 7.40 & 0.00 & 0.02 & 0.27 \\
11.20 & 11.18 & -0.18 & 0.03 & 0.26 \\
18.80 & 18.76 & -0.21 & 0.05 & 0.26 \\
37.03 & 37.06 & +0.08 & 0.05 & 0.13 \\
74.07 & 74.10 & +0.04 & 0.03 & 0.04 \\
\hline
\end{tabular}

average of six determinations.

\section{Effect of foreign ions}

In order to ascertain the possible interference of the diverse ions, thallium determination was carried out with an aliquot containing $11.20 \mathrm{mg}$ of $\mathrm{Tl}(\mathrm{III})$ in the presence of various metal ions and anions. The non-interfering ions are listed in Table 3. However, $\mathrm{Pd}(\mathrm{II}), \mathrm{Hg}(\mathrm{II}), \mathrm{Cr}$ (III) and Sn(IV) interfere severely with positive error. The interference of $\mathrm{Pd}(\mathrm{II}), \mathrm{Hg}(\mathrm{II})$ and $\mathrm{Sn}(\mathrm{IV})$ is due to the release of EDTA from their EDTA complexes on the addition of the reagent. The interference of $\mathrm{Cr}$ (III) is mainly due to the deep purple color of its EDTA complex, which makes the detection of the end point rather difficult. In the case of $\mathrm{Hg}(\mathrm{II})$, interference can be avoided by premasking the metal ions with acetyl acetone.

\section{Application}

In order to explore the utility of the proposed method, quantitative analysis of complexes and synthetic mixtures of thallium were carried out. The analytical reports of such samples are given in Tables $4 \& 5$. From these results it can be concluded that the proposed method can be conveniently employed for rapid analysis of such samples. 
Table 3. Determination of $11.20 \mathrm{mg}$ of $\mathrm{Tl}(\mathrm{III})$ in the presence of diverse metal ions

\begin{tabular}{|c|c|c|c|}
\hline Metal ions & Quantity added (mg) & Thallium found ${ }^{\mathrm{a}}(\mathrm{mg})$ & Relative error (\%) \\
\hline $\operatorname{Mg}(\mathrm{II})$ & 30 & 11.18 & -0.17 \\
\hline $\mathrm{Mn}(\mathrm{II})$ & 40 & 11.17 & -0.26 \\
\hline $\mathrm{Co}(\mathrm{II})$ & 150 & 11.21 & +0.09 \\
\hline $\mathrm{Ni}(\mathrm{II})$ & 150 & 11.18 & -0.17 \\
\hline $\mathrm{Cu}(\mathrm{II})$ & 100 & 11.18 & -0.17 \\
\hline $\mathrm{Zn}(\mathrm{II})$ & 200 & 11.20 & 0.00 \\
\hline $\mathrm{Cd}(\mathrm{II})$ & 100 & 11.22 & +0.17 \\
\hline $\mathrm{Pb}(\mathrm{II})$ & 200 & 11.20 & 0.00 \\
\hline $\mathrm{La}(\mathrm{II})$ & 200 & 11.20 & 0.00 \\
\hline $\mathrm{Hg}(\mathrm{II})^{\mathrm{b}}$ & 15 & 11.21 & +0.09 \\
\hline $\mathrm{Y}(\mathrm{III})$ & 200 & 11.20 & 0.00 \\
\hline $\operatorname{Ir}(\mathrm{III})$ & 25 & 11.16 & -0.35 \\
\hline $\mathrm{Al}(\mathrm{III})$ & 50 & 11.16 & -0.35 \\
\hline $\mathrm{Bi}(\mathrm{III})$ & 15 & 11.18 & -0.17 \\
\hline $\mathrm{Rh}(\mathrm{III})$ & 50 & 11.20 & 0.00 \\
\hline $\mathrm{Ru}(\mathrm{III})$ & 10 & 11.17 & -0.26 \\
\hline $\mathrm{Au}(\mathrm{III})$ & 20 & 11.19 & -0.09 \\
\hline As(III) & 50 & 11.20 & 0.00 \\
\hline $\mathrm{Sb}(\mathrm{IV})$ & 10 & 11.50 & -0.44 \\
\hline $\mathrm{Pt}(\mathrm{IV})$ & 50 & 11.20 & 0.00 \\
\hline $\mathrm{Se}(\mathrm{IV})$ & 100 & 11.22 & +0.17 \\
\hline $\mathrm{U}(\mathrm{VI})$ & 50 & 11.18 & -0.17 \\
\hline $\mathrm{W}(\mathrm{VI})$ & 30 & 11.16 & -0.35 \\
\hline $\mathrm{Cl}^{-}$ & 200 & 11.20 & 0.00 \\
\hline $\mathrm{CH}_{3} \mathrm{COO}^{-}$ & 200 & 11.18 & -0.17 \\
\hline Phosphate & 100 & 11.20 & 0.00 \\
\hline Citrate & 100 & 11.22 & +0.17 \\
\hline Tartarate & 100 & 11.21 & +0.09 \\
\hline Acetate & 50 & 11.22 & +0.17 \\
\hline Borate & 150 & 11.21 & +0.09 \\
\hline Sulphate & 75 & 11.20 & 0.00 \\
\hline Oxalate & 100 & 11.21 & +0.09 \\
\hline
\end{tabular}

${ }^{a}$ Average of four determinations; ${ }^{b}$ pre-masked using acetyl acetone.

Table 4. Analysis of thallium complexes

\begin{tabular}{lccc}
\hline Complexes & $\begin{array}{c}\text { Thallium } \\
\text { calculated }(\%)\end{array}$ & $\begin{array}{c}\text { Thallium } \\
\text { found }^{*}(\%)\end{array}$ & $\begin{array}{c}\text { Relative } \\
\text { error }(\%)\end{array}$ \\
\hline $\mathrm{Tl}\left(\mathrm{C}_{4} \mathrm{H}_{7} \mathrm{~N}_{4} \mathrm{~S}\right)^{\mathrm{a}}$ & 58.83 & 58.98 & +0.25 \\
$\left.\mathrm{Tl}_{(} \mathrm{C}_{3} \mathrm{H}_{5} \mathrm{~N}_{4} \mathrm{~S}\right)^{\mathrm{b}}$ & 61.37 & 61.30 & -0.11 \\
$\mathrm{Tl}^{\mathrm{b}}\left(\mathrm{C}_{5} \mathrm{H}_{9} \mathrm{~N}_{4} \mathrm{~S}\right)^{\mathrm{c}}$ & 56.55 & 56.50 & -0.08 \\
$\mathrm{Tl}\left(\mathrm{C}_{2} \mathrm{H}_{2} \mathrm{~N}_{3} \mathrm{~S}_{2}\right)^{\mathrm{d}}$ & 60.73 & 60.56 & -0.27 \\
\hline
\end{tabular}

Thallium complexes of a4-amino-5-mercapto-3-ethyl-1,2,4-triazole; ${ }^{\text {b4- }}$ amino-5-mercapto-3-methyl-1,2,4-triazole; ' 4 -amino-5-mercapto-n-propyl-1,2,4-triazole; ${ }^{\mathrm{d}} 5$-amino-2-mercapto-1,3,4-thiadiazole. *Average of four determinations.

Table 5. Determination of thallium in synthetic mixtures

\begin{tabular}{lccc}
\hline $\begin{array}{l}\text { Alloy } \\
\text { composition }\end{array}$ & $\begin{array}{c}\text { Percentage } \\
\text { of thallium }\end{array}$ & $\begin{array}{c}\text { Thallium } \\
\text { found }(\%)^{\mathrm{a}}\end{array}$ & $\begin{array}{c}\text { Relative } \\
\text { error }(\%)\end{array}$ \\
\hline $\mathrm{Tl}+\mathrm{Zn}+\mathrm{Cd}$ & 18.80 & 18.77 & -0.16 \\
$\mathrm{Tl}+\mathrm{Pb}+\mathrm{Sb}$ & 11.20 & 11.19 & -0.08 \\
$\mathrm{Tl}+\mathrm{Se}+\mathrm{Co}$ & 37.03 & 37.05 & +0.05 \\
$\mathrm{Tl}+\mathrm{Pt}+\mathrm{Pb}$ & 74.07 & 74.09 & +0.02 \\
$\mathrm{Tl}+\mathrm{Cu}+\mathrm{Zn}$ & 37.03 & 37.04 & +0.02 \\
$\mathrm{Tl}+\mathrm{Y}+\mathrm{Zr}$ & 11.20 & 11.20 & 0.00
\end{tabular}

${ }^{\mathrm{a} A v e r a g e ~ o f ~ f o u r ~ d e t e r m i n a t i o n s . ~}$

\section{Conclusions}

The method is simple and rapid, does not require any heating for the quantitative release of EDTA from Tl(III)-EDTA complex. The reagent does not form any precipitate either with $\mathrm{Tl}(\mathrm{III})$ or with the titrant under the experimental conditions. This facilitates the detection of sharp end point. The proposed method is fairly selective for the rapid analysis of thallium in the presence of various other ions.

\section{References}

1. Amar, M.M.; Pribil, R.; Tawakkol, M.S.; Egypt. J. Pharm. Sci. 1978, 17, 21 (CA 1979, 90:13228).

2. Kaluba, F.Y.; Platunova, N.B.; Zhurnal Analiticheskoi Khimii 1973, 28, 1009 (CA 1973, 79: 73253).

3. Tanaka, T.L.; Yakugaku Zasshi 1973, 93, 252 (CA 1973, $78: 131678)$

4. Narayana, B.; Gajendragad, M.R.; J. Indian Chem. Soc. 1987, 64, 620. 
5. Shetty, A.N.; Gadag, R.V.; Gajendragad, M.R.; Indian J. Chem. $198827 A, 82$

6. Rao, B. M.; Narayana, B.; Acta Indica Chem. 1993, 18C, 193.

7. Narayana, B.; Jose, P. L.; Karunakaran, V.; Gajendragad, M.R.; Asian J. Chem. 1993, 5, 115.

8. Rao, B. M.; Narayana, B.; Turk. J. Chem. 1993, 17, 138.

9. Narayana, B.; Abraham, J.; Praveen Chandra, N.H.; Acta Indica Chem. 1993, 19, 48.

10. Shetty, P.; Shetty, A. N.; Khader, A.M.A.; Gadag, R.V.; Indian J. Chem. Technol. 1994, 1,129.

11. Joseph, A.; Narayana, B.; Asian J. Chem. 1994, 6, 233.

12. Nambiar, C.H.R.; Narayana, B.; Rao, B.M.; Mathew, B.; Analyst 1995, 120, 1843.

13. Vasundhara, B.R.; Shetty, A.N.; Gadag, R.V.; Bulletin of Pure and Applied Sciences 1995, 14,1.

14. Rao, B.M.; Narayana, B.; Ann. Chim. (Rome, Italy) 1995, 85, 105 (CA 1995, 123:73703).

15. Mathew, B.; Narayana, B.; Rao, B. M.; Nambiar, H. R.; Ramachandra, B.; Mikrochim. Acta 1996, 122, 295.

16. Joesph, A.; Mathew, B.; Narayana, B.; J. Indian Chem. Soc. 1996, 73, 633 .

17. Nambiar, C.H.R.; Narayana, B.; Rao, B.M.; Biju, M.; J. Indian Chem. Soc. 1998, 75, 265.
18. Joseph, A.; Narayana, B.; Bhat, K. S.; J. Indian Chem. Soc. 1999, 76, 511.

19. Shetty, P.; Shetty, A.N.; Gadag, R.V. ; Indian J. Chem. Technol. 2000, 7, 227.

20. Gopalakrishna bhat, N.; Narayana, B.; Sreekumar, N.V.; Ann. Chim. (Rome, Italy) 2002, 92, 139.

21. Agarwal, R.C.; Srivastava, A.K.; Indian J. Chem. 1996, 4, 359.

22. Vogel, A. I.; A Text Book of Quantitative Inorganic Analysis, $3^{\text {rd }}$ ed.; Longmann: London, 1968, pp. 390, 533, 549, 550.

23. Saito, K.; Terrey, H.; J. Chem. Soc. 1956, 4701 (CA 1957, 51:4194).

24. Pribil, R.; Talanta 1967, 14, 613.

25. Crisan, I.A.; Bolyai, M.P.; Ser. Chem. 1967, 12, 39.

26. Verma, K.K.; Rawat, R.; Chem. Anal. (Warsaw, Pol.) 1980, 25, 729.

27. Van Nieuwenburg, C.J.; Gillis, J.; Reagents for Quantitative Inorganic Analysis, $1^{\text {st }}$ ed.; Elesvier: Amsterdam, 1948, p.160.

28. Gadag, R.V.; Gajendragad, M.R.; Indian J. Chem. 1978, 16A, 703.

29. Gupta, B.K.; Gupta, D.S.; Dikshit, S.K.; Agarwal, U.; Indian J. Chem. 1977, 15A, 624. 